\title{
Empowering Asnaf Agropreneurs Through Economic Development Programs by Selected Zakat Institutions
}

Noorfazreen Mohd Aris, Mohd Faizal P.Rameli, Dziauddin Sharif, Sarah Dina Mohd Adnan, Mariam Farhana Md Nasir, Sharipah Amirah Abas

To Link this Article: http://dx.doi.org/10.6007/IJARBSS/v11-i11/11587～DOI:10.6007/IJARBSS/v11-i11/11587

Received: 17 September 2021, Revised: 20 October 2021, Accepted: 30 October 2021

Published Online: 14 November 2021

In-Text Citation: (Aris et al., 2021)

To Cite this Article: Aris, N. M., P.Rameli, M. F., Sharif, D., Adnan, S. D. M., Nasir, M. F. M., \& Abas, S. A. (2021). Empowering Asnaf Agropreneurs Through Economic Development Programs by Selected Zakat Institutions. International Journal of Academic Research in Business and Social Sciences, 11(11), 963 - 972.

Copyright: (c) 2021 The Author(s)

Published by Human Resource Management Academic Research Society (www.hrmars.com) This article is published under the Creative Commons Attribution (CC BY 4.0) license. Anyone may reproduce, distribute, translate and create derivative works of this article (for both commercial and non-commercial purposes), subject to full attribution to the original publication and authors. The full terms of this license may be seen at: http://creativecommons.org/licences/by/4.0/legalcode

Vol. 11, No. 11, 2021, Pg. $963-972$

Full Terms \& Conditions of access and use can be found at http://hrmars.com/index.php/pages/detail/publication-ethics 


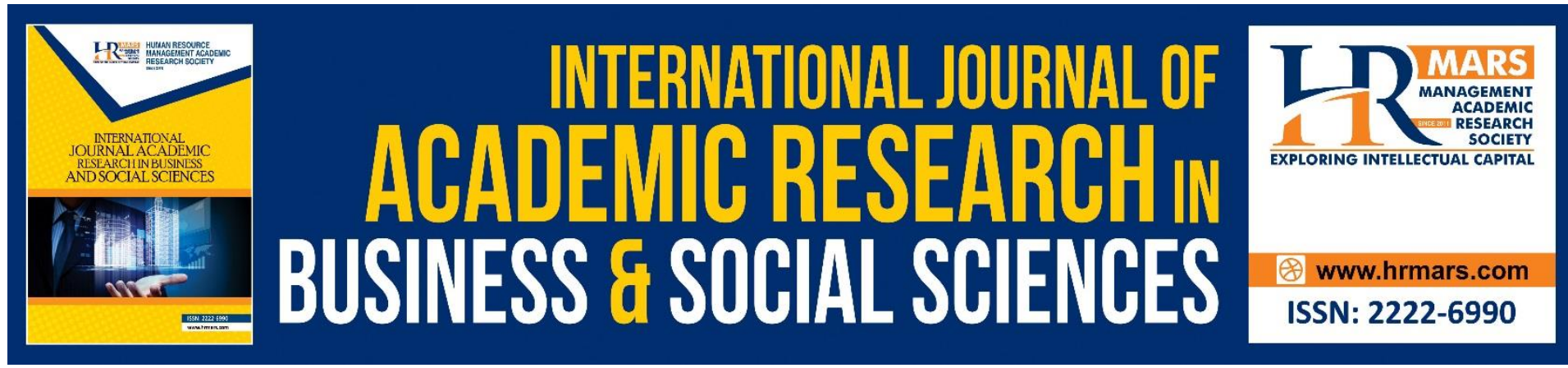

\title{
Empowering Asnaf Agropreneurs Through Economic Development Programs by Selected Zakat Institutions
}

\author{
Noorfazreen Mohd Aris ${ }^{1}$, Mohd Faizal P.Rameli², Dziauddin \\ Sharif ${ }^{3}$, Sarah Dina Mohd Adnan ${ }^{4}$, Mariam Farhana Md Nasir ${ }^{5}$, \\ Sharipah Amirah Abas ${ }^{6}$ \\ 1,4,5Lecturer, Academy of Contemporary Islamic Studies (ACIS), UiTM Cawangan Melaka \\ Malaysia, 2,3Senior Lecturer, Academy of Contemporary Islamic Studies (ACIS), UiTM \\ Cawangan Melaka Malaysia, ${ }^{6}$ Postgraduate Student, Academy of Contemporary Islamic \\ Studies (ACIS), UiTM Shah Alam, Malaysia
}

\begin{abstract}
The poverty issue among asnaf has still been the main focus of Zakat Institutions in Malaysia. Various forms of assistance have been given to asnaf for them to get out of poverty, including capital assistance, equipment and guidance training. However, many asnaf are still plagued by poverty. The objective of this study is to look at the form of a special Economic Development Program to produce asnaf agropreneurs in the states involved by using the method of interviews and library research as data collection methods. Semi-structured interview questions were conducted with informants involved in the implementation of the asnaf agropreneur program for the states involved. The result of the study found that four states that have conducted special agricultural programs for asnaf entrepreneurs. The programs are Program Pemerkasaan Asnaf (Proper A) in Perak, the Pineapple Planting Program in Penang, the Human Development Plan in Perlis and the Human Development Model in Kelantan. The farmer entrepreneurship program implemented by the Zakat Institution for asnaf is one of the best initiatives to make agriculture a source of income because the field of agriculture is still relevant and has the potential to be developed for the economic development of the asnaf.
\end{abstract}

Keywords: Poverty, Asnaf Entrepreneur, Economic Development, Agriculture

\section{Introduction}

The poverty issue has always been a major agenda that must be resolved at the national and global levels. Various initiatives are undertaken by the institutions responsible to help to alleviate the issue. In Malaysia, zakat institutions play a role in resolving this issue, especially those involving asnaf (Rahman, 2019). Asnaf are a group of people who areentitled to receive zakat assistance, that is, the group determined by Allah SWT to receive zakat and alms. Fakir, miskin, amil, mualaf, slave, fi sabilillah, and musafir are among those in asnaf group. The method that can help asnaf in continuing their survival is the provision of zakat assistance in 
the form of food, finance, equipment and others. Zakat instruments play a role in improving socio-economic status, income, eradicating poverty, reducing income distribution gaps (Ismail et al., 2020) social security guarantees, and purification of the souls of the asnaf (Haron \& Rahman, 2016). Every rich people must fulfil the rights of the poor by withdrawing zakat from their property. Meanwhile, at the distribution stage, the Zakat Institutions are tasked to find the asnaf to be given the zakat assistance to them. The distribution of zakat needs to be done very efficiently to ensure that the asnaf are protected and later can eradicate poverty.

Among the efforts made by the Zakat Institutions is by developing farmer entrepreneurs among the asnaf. Involvement as a farmer entrepreneur plays an important role to reduce the problem of unemployment and poverty (Kumar, 2019). While there are assumptions that say agriculture is traditional, unprofitable and has no potential to change the quality of life (Ahmed \& Sum, 2017), as well as lack of encouragement from family (Abiddin et al., 2015), this negative perception needs to be eradicated and agriculture is made as a job and it needs to be expanded and developed at all levels because the involvement of entrepreneurs in agriculture is still low compared to other fields in Malaysia (Sarmila et al., 2014). The field of agriculture has great potential to be developed for the economic development of the community and the country. Thus, the farmer entrepreneur program conducted by the Zakat Institutions for asnaf is one of the best initiatives to make agriculture a source of income.

\section{Literature Review}

Entrepreneur is a person who runs a company. Entrepreneurship meanwhile is everything related to the entrepreneur or entrepreneurial activities and skills (Dewan Bahasa \& Pustaka, n.d). The entrepreneur term is derived from the English word "entrepreneur" which comes from the French language "entreprendre" which means to undertake (task) or try. In 1725, the word "entrepreneur" was used by an economist named Richard Cantillon to clearly associate this term with business activities (Hashim, et al., 2009). According to Tuluce (2015) in his study, most entrepreneurship is related to risk, innovation and creative thinking. An entrepreneur can be described as a person who creates a new business in facing risks and uncertainties to achieve profit, identify significant opportunities and gather the necessary resources to take advantage of them. An entrepreneur is also a person who organizes, manages and bears the risks of a business or enterprise (Swanson, 2017). Now, it is clear that the difference between entrepreneurs and non-entrepreneurs is the willingness of the entrepreneurs to take risks, determination to work to form and develop a business, maximize self -potential and take advantage of opportunities received.

Meanwhile, asnaf entrepreneurs are defined as individuals who go through a process of business creation, are able to bear duties, being responsible and try as traders who are stimulated with help and encouragement from Islamic religious councils or state zakat institutions (Jumbri, 2007). Asnaf who have skills, talents and interests in entrepreneurship can apply for capital assistance from Islamic religious councils or state zakat institutions to allow them to be involved in the business (Ahmad, 2012). This is to help the asnaf get out of poverty and subsequently become a zakat payer after becoming a successful entrepreneur. Asnaf agropreneurs are a group of asnaf who receive assistance from the Islamic religious council or state zakat institutions for the purpose of becoming entrepreneurs in the field of business, agriculture or livestock. The distribution of zakat in the form of business capital is a paradigm shift aimed at improving the living standards of the asnaf (Rahman et al., 2014). 
These asnaf have the constraint of lack of finance to run a business on their own, so they are given full assistance and attention by the state zakat institution. Efforts that have been implemented in developing the asnaf, especially in the economic field should be continued to improve the level and quality of asnaf with methods of joint venture and collaboration (Ahmad, 2012). Furthermore, to ensure that the asnaf are able to become truly qualified and potential entrepreneurs, they need to go through a phase of exposure, education, implementation, marketing and monitoring as they need to plan and generate the asnaf economy towards becoming entrepreneurs (Balwi \& Halim, 2008). Jumbri and Zainudin (2011) have proposed Model Pembangunan Usahawan Asnaf (MAPUA) which emphasizes the concept of 5P namely pendedahan, pendidikan, pelaksanaan, pemasaran dan pemantauan. The study found that the involvement and interest of the asnaf are essential to ensure the effectiveness of the program. Ibrahim (2008), proposed an integrated plan for zakat asnaf by reviewing the form and amount of zakat distribution given. The amount of distribution should take into account the short term as to meet the basic and long-term needs of sources of income in the future. Therefore, it is clear that the most influential elements on the effectiveness of a program are capital and interest apart from solid training and coaching factors.

The implementation of the asnaf economic development program is held specifically for the asnaf as a platform for those who are interested in venturing into business with assistance from their respective state zakat institutions, either in the form of business capital, working capital, skills courses and so on to produce competitive asnaf entrepreneurs (Meerangani \& Azman, 2019). Lembaga Zakat Selangor (LZS) has outlined the implementation of the distribution of zakat money by way of educating, imparting knowledge, guiding and developing zakat asnaf based on their potential (Yusof, 2011). Lembaga Zakat Negeri Kedah (LZNK) has introduced Skim Bantuan Jayadiri aimed at providing capital assistance to eligible asnaf small businesses. The scheme aims to generate a stable source of income and be able to change the status of asnaf to zakat payers (Abu Hassan, Rusli, Albasri, \& Ahmad, 2018). Next, Majlis Agama Islam dan Adat Istiadat Melayu Perlis (MAIPs) has established Skim Agihan Program Peningkatan Ekonomi Asnaf (MAIPs, 2019). Entrepreneurial programs conducted by Zakat Institutions have given a very effective impact on the economic status of asnaf and can also provide a stimulus to the national economy (Rahman, 2016). This effort provides a bright opportunity for asnaf to develop themselves and their families because they are not only given business capital but also knowledge, courses and skills in order to produce successful asnaf entrepreneurs and directly generate the national economy.

\section{Research Objective}

This research is conducted to observe a specific Economic Development Program to produce asnaf agropreneur for the states involved which are Perak, Pulau Pinang, Perlis and Kelantan.

\section{Research Methodology}

This research is qualitative research using interview and library research methods as data collection methods. Semi-structured interview questions were conducted with the officers in charge and involved in the implementation of the asnaf agropreneur program for the states involved. Next, library research was also conducted to obtain information on the background of the research, research problems and past research obtained from books, journals, conference papers, websites and so on. 


\section{Research Finding}

\section{Roles and Economic Development Program by Selected Zakat Institutions}

The management of Zakat Institutions in Malaysia is evolving in terms of governance, collection and distribution. Good governance is vital in the management of zakat to ensure the collection and distribution of zakat are in accordance with Islamic law (Rahman, 2019). Table 1 shows the total collection and distribution of zakat in selected states, which are Perak, Penang, Perlis and Kelantan which provide agricultural specific programs for asnaf entrepreneurs. The total collection and distribution of zakat in each state increased from 2018 to 2019. Perak shows the highest increase in total collection and distribution of zakat compared to the three states, which is an increase of $17.5 \%$ for collection and $12.21 \%$ for distribution, for 2019.

Table 1. Performance of Zakat Collection and Distribution

\begin{tabular}{|l|c|c|c|c|}
\hline \multirow{2}{*}{ State } & \multicolumn{2}{|c|}{2018} & \multicolumn{2}{c|}{2019} \\
\cline { 2 - 5 } & Collection & Distribution & Collection & Distribution \\
\hline Perak & $176,239,032$ & $175,891,153$ & $207,187,053$ & $197,376,261$ \\
\hline Pulau Pinang & $114,826,389$ & $101,010,171$ & $121,483,234$ & $110,989,506$ \\
\hline Kelantan & $183,034,916$ & $189,017,291$ & $195,138,060$ & $181,936,430$ \\
\hline Perlis & NA & NA & NA & NA \\
\hline
\end{tabular}

The increase in terms of collection and distribution can diversify efforts to help the needy asnaf. Among the efforts made is to produce asnaf entrepreneurs. Asnaf entrepreneurs are a group of asnaf formed to become entrepreneurs. Zakat institutions have introduced capital assistance or equipment to asnaf who are interested in venturing into the entrepreneurial sector (Abai, 2020). Capital assistance or equipment provided is intended to be a start-up fund or addition to existing business activities (Rahman, Basah, Abdullah, Nooh, \& Fauzi, 2014). Eligible asnaf will also be given training and skills.

\section{Majlis Agama Islam dan Adat Melayu Perak (MAIPk)}

Majlis Agama Islam dan Adat Melayu Perak (MAIPk) was officially incorporated as a government statutory body in 1992 under the Administration of Islamic Law Enactment 1992. The enactment was then replaced by the Administration of Islamic Law Enactment (Perak) 2004 and in effect until today. MAIPk aims to improve the socio-economic status of the ummah through the strengthening of effective and dynamic baitulmal management by practising excellent governance based on transparency, integrity and high professionalism.

Next, for the state of Perak under Majlis Agama Islam dan Adat Melayu Perak (MAIPk), the productive asnaf are put under asnaf empowering programs to nurture talents and self abilities in order to attempt to improve the abilities, skills and productivity in the field of empowerment of the selected clusters. For example, under the Program Pemerkasaan 
Ekonomi Asnaf (PROPER A), participants are trained to become knowledgeable, independent, resilient and competitive entrepreneurs. Among the areas of focus are manufacturing, services, branding and marketing of products, agriculture and livestock (MAIPk, 2019).

\section{Zakat Pulau Pinang (ZPP)}

Syarikat As-Sahabah Urus Zakat Sdn. Bhd. (ASUZ) was registered by Majlis Agama Islam Negeri Pulau Pinang (MAINPP) as an amil staff company on behalf of MAINPP incorporated under the Companies Act 1965 as a private limited company wholly owned by MAINPP. ASUZ has started its full operations by using the name of Pusat Urus Zakat Negeri Pulau Pinang or in short PUZ as the office name for ASUZ in order to maintain the 'public interest' towards the zakat institution. Later, in 2012, the name and logo of Pusat Urus Zakat, Majlis Agama Islam Negeri Pulau Pinang was rebranded to a new corporate name which is Zakat Pulau Pinang. Among the goals of the establishment of Zakat Pulau Pinang is to increase zakat collection in Penang, introduce a more systematic zakat collection system through computerized operations, as an element to remember and be aware to Muslims that zakat can play a major role in strengthening the economy of Muslims, provide payment facilities and distributing zakat money more effectively and fairly so that zakat payers and Muslims are confident and satisfied (ZPP, 2021). ZPP has provided the Economic Asnaf Program which consists of catering, Sewing, Farming, Business, Atrium and Cafe. In these programs, eligible asnaf are also given the necessary training and skills (ZPP, 2021).

\section{Majlis Agama Islam dan Adat Istiadat Melayu Perlis (MAIPs)}

The establishment of MAIPs is in line with the consent of DYMM Tuanku Al-Marhum Syed Putra Ibni Al-Marhum Syed Hassan Jamalullail, the 6th King of Perlis who bestowed the Undang-Undang Tubuh Kerajaan Perlis in 1948. After 15 years of playing a role in handling Islamic affairs in the state of Perlis starting in 1948, in 1963, an amendment was made to the Administration of Islamic Law No. 3 which was approved to place the Baitulmal as a functioning body for the economic development of Muslims. Its function was implemented a year later through the provisions of the Perlis State Law, Phase 4, Administration of Muslim Law Enactment No. 3/1964. This amendment has elevated the position of MAIPs to move more efficiently and bear great responsibility in realizing the socio-economic development agenda of Muslims, especially in the State of Perlis (MAIPs, 2011).

Among the roles of MAIPs is to use the collection and distribution of zakat as well as wakaf and baitulmal property, encourage, guide, assist, work for the progress and economic and social welfare of the Muslim community in Perlis in accordance with Islamic law. To realize this role, MAIPs has established Akademi Transformasi Asnaf MAIPs Sdn Bhd (ATAM) to transform asnaf more powerfully. The mission of ATAM Sdn Bhd is to develop human capital and the economic status of asnaf so that they can be independent and even be a contributor to the economic strength of the ummah (MAIPs, 2019). MAIPs provides Skim Bantuan Pembangunan Ekonomi to channel capital assistance and equipment to eligible asnaf to help them start, strengthen business or purchase equipment to start a business (MAIPs, 2019). Among the courses that have been conducted is Latihan Pembentukan Usahawan (LPU) course which focuses on young asnaf entrepreneurs as an initiative to pave the way to grow their business (e-Warta MARA, 2020). 


\section{Majlis Agama Islam dan Adat Istiadat Melayu Kelantan (MAIK)}

Majlis Agama Islam dan Adat Istiadat Melayu Kelantan (MAIK) was established on 17 Safar 1334 / 24 December 1915 through a declaration by HRH Sultan Muhammad IV. Its establishment aims to advise His Majesty the Sultan as the head of the Islamic religious affairs and Malay customs of Kelantan. MAIK's mission is to uphold Islam and increase the well-being and prosperity of Muslims in Kelantan by focusing on the following aspects; management of zakat, infaq, wakaf and baitulmal as well as trustworthy and professional mosque administration, dakwah efforts, welfare and the development of society socio-economy that is well planned, innovative and continuous. MAIK provides capital assistance, equipment and guidance as well as training to asnaf entrepreneurs. Skim Bantuan Pemulihan Perniagaan was established to provide capital assistance to run a small business where priority is given to asnaf who have run a business with an assistance rate of RM5,000.00 (MAIK, 2021).

The Asnaf Economic Development Program that has been carried out is a long-term process and one of the mechanisms for the distribution of zakat to the poor and needy asnaf. The program aims to help produce entrepreneurs among the asnaf to increase their income so that they can support their families and in the long term, be able to pay zakat.

\section{Efforts of Selected Zakat Institutions in Empowering Asnaf Agropreneur}

Zakat institutions have intensified efforts to produce asnaf agropreneurs to help them to get out of poverty. Among the zakat institutions that have developed asnaf agropreneurs through asnaf economic development programs are Majlis Agama Islam dan Adat Melayu Perak (MAIPk), Zakat Pulau Pinang, Majlis Agama Islam dan Adat Istiadat Melayu Perlis (MAIPs) and Majlis Agama Islam dan Adat Melayu Kelantan (MAIK). Special agricultural programs have been implemented for asnaf as a productive effort in distributing zakat funds. Table 2 below shows the economic development programs.

Table 2. Asnaf Economic Development Programs (Agriculture)

\begin{tabular}{|c|c|c|c|c|}
\hline BIL & STATE & PROGRAM NAME & YEAR & PERIOD \\
\hline 1 & Perak & Program Pemerkasaan Asnaf (Proper A) & 2019 & 5 Years \\
\hline 2 & $\begin{array}{c}\text { Pulau } \\
\text { Pinang }\end{array}$ & Pineaple Planting Program & 2020 & 3 Years \\
\hline 3 & Kelantan & Human Development Plan & 2017 & 5 Years \\
\hline 4 & Perlis & Human Development Model & 2014 & 5 Years \\
\hline
\end{tabular}

\section{Asnaf Empowerment Program (Proper A) by MAIPk}

MAIPk has started Program Pemerkasaan Asnaf (Proper A) in 2019 which involves a total of 20 asnaf participants with the condition of owning their own land or family area of $100 \times 100$ feet. The specific agriculture carried out is Chili Fertigation with the initial capital to clear the land is RM1,500. This program is divided into four phases, firstly, an interview will be conducted and those who are successful will be given Seminar Hijrah Minda. For the second phase, certain companies are appointed to teach the basics of business, finance basics, accounting basics and also other basics related to business. Meanwhile, in the third phase, the goods or equipment are supplied according to the needs of participants of the program with a maximum amount of RM5000, and in the fourth phase, there will be a guidance and monitoring phase conducted for 8 months. 


\section{Pineaple Planting Program by Zakat Pulau Pinang}

Zakat Pulau Pinang has developed the Pineaple Planting Program with a fund allocation of $\mathrm{RM} 250,000$. This program is carried out in collaboration with Lembaga Perindustrian Nanas Malaysia (LPNM) since 2020. A total of 6 eligible male asnaf have become participants in this program. A total of almost ninety thousand trees consisting of MD2 and Moris have been planted on 12 acres of wakaf land belonging to Penang Wakaf. The land is leased by Zakat Pulau Pinang. Asnaf participants are given an allowance of RM1,000 per month.

\section{Human Development Plan Program by MAIK}

Projek Agroekonomi Asnaf Fakir \& Miskin Desa Alam Shah, Kelantan has been carried out under the Human Development Plan starting from 2016 with a fund allocation of RM10 Million by the Lembaga Zakat Selangor. The plan involves three phases, which are first, basic/refining, second, consolidation and third, continuous. The asnaf participants involved are a total of 28 people who have families. The concept of this program is assistance in the form of group housing along with facilities and employment to asnaf who are involved with development from the aspects of education, social and health. The main crop involved is the Chili plant and intercrops consist of stem cucumbers, corn, okra, cucumber pickers \& sweet squash. It is conducted on 29 acres of land while 8 acres for housing for the placement of the asnaf participants involved. For the success of this project, a plantation contract was signed with Nestle and advice from the Area Farmers' Organization is also received.

\section{Human Development Model Program by MAIPs}

Human Development Model Program that was carried out in Taman Desa Asnaf, Chuping, Perlis by MAIPs also received fund from LZS same as Desa Alam Shah, Kelantan. Residential facilities have been developed consisting of 52 semi-D houses for the placement of asnaf participants. The agricultural activity carried out here is the Rockmelon crop which started in 2014 and involved a total of 35 asnaf. The land area is 8 acres with 14 greenhouses. Participants were also given courses or other skills apart from agriculture such as sewing, baking and soft skill courses.

\section{Conclusion}

The distribution of zakat in the form of the implementation of economic programs is a thoughtful idea to help the asnaf out of poverty. Efforts carried out in Perak, Penang, Perlis and Kelantan that focus on agriculture will be the best example to other states that have not yet done so. The field of agriculture is crucial to be developed not only for the well-being of the asnaf involved but also to be able to supply food needs to the country. The program needs to be looked at in more depth for future studies, especially the impact on the asnaf economy.

\section{Acknowledgement}

Thanks to the Ministry of Higher Education Malaysia (MOHE) for approving and fully funding this study under the Fundamental Research Grant Scheme (FRGS), Research Code: 600IRMI/FRGS 5/3 (247/2019).

\section{Corresponding Author}

Noorfazreen Mohd Aris

Lecturer Academy of Contemporary Islamic Studies (ACIS), UiTM Cawangan Melaka (Jasin Campus), Malaysia 
Email: noor_areen@uitm.edu.my.

\section{References}

Abai, D. S. A., Awang, M. D., Yusoff, A. N. M., Majid, A. A., \& Hamli, H. (2020). Bentuk Bantuan Modal Agihan Zakat Asnaf dan Pencapaian Usahawan Asnaf di Malaysia: Kajian Empirikal. Malaysian Journal of Social Sciences and Humanities (MJSSH), 5(1), 93-99. https://doi.org/10.47405/mjssh.v5i1.353.

Abiddin, N. Z., Anuar, M. A. M., \& Abdullah, A. (2015). Penglibatan Belia dalam Pertanian Komersial dan Perkembangan Industri Pertanian di Malaysia. SIPATAHOENAN: SouthEast Asian Journal for Youth, Sports and Health Education, 1(1), 99-108.

Ahmad, S. (2012). Membangun Keusahawanan Asnaf: Analisis Konsep Model Pemindahan Teknologi. The Malaysian National Economic Conference VII (PERKEM VII). 709-715.

Ahmed, M. C., \& Sum, S. M. (2017). Belia Dan Keusahawanan Tani : Kajian Faktor-Faktor Yang Mempengaruhi Penglibatan Belia Sebagai Usahawan Tani Di Pasir Puteh, Kelantan. Journal for Scholarly Discourse, 1(1), 1-18.

Balwi, M. A., \& Halim, A. H. A. (2008). Mobilisasi Zakat Dalam Pewujudan Usahawan Asnaf: Satu Tinjauan. Shariah Journal, 16, 567-584.

Dewan Bahasa dan Pustaka (n.d.). Kamus dewan edisi keempat. Retrieved from https://prpm.dbp.gov.my/cari1?keyword=usahawan

Haron, M. S., \& Rahman, R. (2016). Pengagihan Zakat Dalam Konteks Kesejahteraan Masyarakat Islam: Satu Tinjauan Berasaskan Maqasid Al-Syari'ah. Labuan E-Journal of Muamalat and Society (LMS), 10, 129-140. Retrieved from https://jurcon.ums.edu.my/ojums/index.php/LJMS/article/view/2581

Hashim, N., Ooi, Y. K., Din, M. S., Hoe, C. H., Ahmad, S., Bakar, H., \& Hussain, M. N. M. (2009). Asas Keusahawanan. Sintok: Professional and Continuing Education Centre (PACE), Universiti Utara Malaysia.

Hassan, N. S. A., Rusli, R. Z. A., Albasri, S. H., Ahmad, R. (2018). Keberkesanan Skim Bantuan Jayadiri Terhadap Asnaf Di Lembaga Zakat Negeri Kedah (LZNK). International Journal of Muamalat December, 2(1), 17-22.

Ibrahim, P. (2008). Pembangunan Ekonomi Melalui Agihan Zakat: Tinjauan Empirikal. Shariah Journal, 16(2), 223-244.

Ismail, I. A., Hussain, M. N. M., \& Hamed, A. B. (2020). Strategi Teraju Ekonomi Asnaf Sdn Bhd (Teras) Sebagai Pemangkin Kejayaan Usahawan Asnaf Di Selangor. International Journal of Zakat And Islamic Philanthropy, 2(1), 145-156.

Jumbri, I. A., \& Zainudin, M. Z. (2011). Pembangunan Modal Insan dalam Kalangan Fakir dan Miskin Sebagai Usahawan: Kajian Kes Di Lembaga Zakat Selangor. Journal of Human Capital Development, 4(2), 41-56.

Kumar, D. (2019). Prospects and challenges of agro-industry in Bangladesh : An agripreneur view. African Journal of Agricultural Research, 14(31), 1379-1389. https://doi.org/10.5897/AJAR2019.14110

Meerangani, K. A., \& Azman, U. K. Z. (2019). Keberkesanan Program Pembangunan Ekonomi Asnaf Oleh Lembaga Zakat Selangor. E-Academia Journal, 8(2), 14-24.

Rahman, A. A. (2019). Pengurusan Institusi Zakat Berdasarkan Maqasid Syariah dan matlamat Pembangunan Lestari (SDG). Journal of Fatwa Management and Research, 17(2), $42-$ 59. http://dx.doi.org/10.33102/jfatwa.volOno0.282

Rahman, A. A., Basah, M. A. Y., Abdullah, M., Nooh, M. N., \& Fauzi, A. A. M. (2014). Keberkesanan Program Usahawan Asnaf Oleh Institusi Zakat dalam 
Menginterpretasikan Keharmonian Ummah. Proceeding of the International Conference on Arabic Studies and Islamic Civilization iCasic 2014 on 4-5 March 2014 at Kuala Lumpur.

Rahman, A. A., Basah, M. Y. A., Abdullah, M., Nooh, M. N., Fauzi, A. A. M., Bakar, M. F. A. (2016). Program Usahawan Bagi Memperkasakan Ekonomi Golongan Asnaf: Pemantauan daripada Aplikasi Myema, Journal of Fatwa Management and Research, 7, 57-74.

Sarmila M. S., Ramli, Z., Lyndon, N., Am, A., Suhana, S., Aznie, R., \& Selvadurai, S. (2014). Pembangunan usahawan tani melalui inisiatif Tanggungjawab Sosial Korporat (CSR): satu kajian kes. Geografia : Malaysian Journal of Society and Space, 10(3), 134-147.

Swanson, L. A. (2017). Entreprenuership and Innovation Toolkit. Creative Commons Attribution.

Tuluce, N. S., \& Asuman, K. Y. (2015). Term of Strategic Entrepreneurship and Schumpeter's Creative Destruction Theory. Procedia Social and Behavioral Sciences, 207, 720-728.

Yusof, M. I. M. (2011). Dana Zakat: Instrumen Pembasmi Kemiskinan Asnaf. Persidangan Zakat Serantau, Pada 28 Mac, 2011 di Legend Hotel, Kuala Lumpur. 